\title{
SUCCESS DETERMINATION BY INNOVATION: A THEORETICAL APPROACH IN MARKETING
}

\author{
RAJ KUMAR GAUTAM
}

\section{INTRODUCTION}

Innovation is the process of creating and implementing new ideas for the success of organization. Innovation management is the key determinant in today's business enviournment. The current business scenario is changing very fast and demands immediate compliance with respect to all areas of business operations. In business the process of innovation starts even before incorporation of company. The idea generation concept is the important factor for success or failure of business. The moment organization further progresses the importance of creativity and innovation increases to meet all the challenges faced by the companies from time to time. The process of innovation can be used to develop new product, quality issues, sales and marketing techniques, creative advertising, to retain and sustain the customer etc. Without proper innovation, it is not possible for the organizations to be effective and efficient which is very important for survival in the competitive era.

The market environment at national and international level is becoming highly competitive and challenging for all types and size of companies. Market offers entry to companies, and is a place to meet fair competition with local and foreign companies. The vast majority of the India's market is exceptionally price sensitive. Firms that keep prices as low as possible outperform those trying to sell more expensive premium models. The Indian economic consumer is aware of quality differences, yet will sacrifice quality for lower price. The main problem with price promotion in India is ineffective means of communicating the deals. In the past few years, India has moved from being a seller's market to being a buyer's market. As a result, advertising has become an important tool in marketing and selling products (Ramachandran, 2000).

In present era companies are wrestling with the changing customer value and orientation. The business enterprises are no longer enjoying the protective measures of the Government; hence, proper innovative market segmentation, positioning and target marketing can lead to profitable position. Liu (1998) observed that as the business environment increases in its scope, dynamic and complexity, the task of grasping its changes becomes increasingly demanding. Chaston (1997) believed that poor marketing is one of the key reasons to explain success and failure of small firms. In the changing marketing atmosphere, the service and experience concepts have also emerged. In the service concept 
customer buys services not products, but in experience concept marketer should create an experience around the product. Marketing practices were found to be a superior predictor of business performance. Muthiah (2006) said that Indian firms are now coming forward to accept professional management with focus on innovation. Marketing orientation significantly predicts economic performance which further depends upon using innovation degree, innovation performance and customer loyalty as intermediate variables (Olivares and Nora, 2003).

In modern business scenario, the market witnesses a fierce competition to gain major share of the market and requires lots of innovative and creative idea's for success, survival and growth of the organizations. There is need to opt for new innovative strategies in the marketing mix areas such as product, price, place and promotion.

\section{REQUIREMENTS OF INNOVATION}

Some of the important requirements of innovation may be: i) Motivating the staff for innovative ideas; the modern companies must encourage their employees for innovative ideas right from product manufacturing to selling of the products. ii) Internal marketing: Employees being insiders have more knowledge about the current affairs and position of the organization and can help the organization for SWOT analysis of the products and services offered by the organization. iii) Providing Resources: to make innovation possible organization must provide appropriate resources like financing, recreation, rewarding and recognition for the idea, appropriate environment to work.

\section{METHODOLOGY}

The research is based on secondary data. To find out the marketing areas which need more innovation and creative strategies, various research papers has been studied relating to marketing and other related fields. The efforts have been made to suggest few points to the marketers to make marketing more effective by using innovation and creativity in the areas of product, price, distribution and promotional aspects.

\section{OBJECTIVES OF STUDY}

The objectives of the study are:

i) to study important aspects of innovation in marketing ii) to identify the core issues in the marketing which needs more attention iii) to make suggestion to the related marketing issues. 


\section{INNOVATION IN MARKETING: A THEORETICAL FRAMEWORK}

At present organizations having innovative ideation and techniques will take lead over the other organizations. Hence, it is highly important for any organization to introduce new strategies in various areas of marketing and customer relationships. The following innovative ideas can lead the companies to success in the market.

\section{1) Generate Business leads through Innovative Ideas}

Right Business leads at right time are the fuel of many businesses. The target audience must realize your business presence in the market. In order to do that, the companies will need to advertise on a regular basis. Marketers should also attend or even address various workshops related to fields for generating the business leads. The Marketers need to focus on following issues:

- Creating the right business circle and frequently communicating with the people related to the business.

- Generating references by way of positive and innovative marketing. It can be achieved by supplying quality products at highly competitive rates and with quick after sales services. The customer would by highly satisfy and will advertise on your behalf which will generate references for the organization.

- To transform the prospects into generating leads and converting the leads to business deals.

- Handling the psychology and quarries of prospects during the lead generation process.

- Using the scientific research methods for lead generation.

\section{2) Take Creative Marketing Initiatives}

Creative modern marketing tools such as online marketing, web marketing and Internet marketing are the requirements for the success of organizations. It is also important to optimize of customer data base, and making right strategies for achieving sales and marketing objectives. The companies need to focus on:

- Highlighting the key performance indicators for online presence.

- Identifying common barriers and challenges that block business results.

- Entering the new market segments for creating new opportunities.

- Taking timely decisions and replying promptly to market changes to achieve desired business results.

\section{3) Design Innovative Product Manufacturing}

The company makes its first contact with product which provides primary value to customer. Starting with the manufacturing strategy, more attention is required to the way in which product quality, process flexibility, delivery dependability and manufacturing cost influence the firm's foreign business (Meijboom and 
Bart, 1997). Inferior quality and outdated products will no longer help in survival. Companies need to replace the outdated products with new innovative product designing, new packaging look, good quality, preferably branded product. In modern era the emerging issues in product management are:

- Use of latest technology has a dramatic impact on the quality and manufacturing process of the product. In the competition driven economy emerging trends, such as new product technologies, creative design are changing very fast in the market.

- Branding is the craze in today's market and is highly important for continuity, consistency and credibility of the product. So, Indian companies should emphasize on strong brand building, maintaining brand and making necessary changes in their brands according to market demands (Urde, 2003).

- The reliable and consistent products are residing in the minds of consumers. So, new product innovation and adopting new cost cutting methods are the requirement of any company.

\section{4) Use Price as tool of Marketing}

Pricing plays significant role in the success of business as it is only $\mathrm{P}$ which generate revenue as rest of the Ps are expense for the organization. Firms are required to be very careful about pricing decisions. The success in marketing depends on the pricing strategies adopted by the companies because customer builds strong association between price and quality. If the product is over priced buyer will stay away but if prices are competitive it has better chance of being sold quickly. So, clear cut policies and innovative idea's relating to discount and allowances are required to meet the pricing challenges.

\section{5) Make Distribution Practices more Effective}

The distribution strategies are needed for matching arrangement and smooth flow of goods and services from producer to customer. The customer is not in habit to wait for product for the long time and wants that it should be available at the right time in the right quantity and at the right place. Place refers to organizational decisions relating to location of outlet, method of transportation and inventory level to be held. Market intermediaries through their contacts, experience, specialization and scale of operation, offer the firm more than it can usually achieve on its own. So companies have to decide about the use of different channels in transferring the goods to consumer by way of using creative ideas and innovative techniques. Tapping the market with changing styles in transport channels, old or unorganized system of transportation may not be effective and to be replaced by latest methods in making the product available. Use of e-marketing or web marketing may help the producer to place the product to large number of buyers. Designing the distribution strategies which meet company and customer objectives and making the product available in the market 
is very important in the present scenario. Company should ensure the maximum coverage of the market by using all available outlets (Joseph et al, 2001). Location of the channel plays an important role to cover the target market and reducing time gap between customer and producer. Modern business organizations must go for surveys or marketing research for selecting the location of the channel. Proper training, continuous monitoring of channels, developing computerized channel management system and use of alternative channels may be useful in attaining the competitive advantage.

\section{6) Achieve Targets by Promotional tools}

In the present era organizations have to manage a complex marketing communication system and to position their products in the minds of customers. The company communicates with its customers by way of advertising, sales promotion, public relation and direct selling. Apart from these advertising methods, advertising through mobiles is an innovative and customer centric approach to reach promising customers. It includes advertising in the form of short message service (sms), mobile alerts, multimedia, messaging service etc. The use of mobile phone advertising can be cost effective, flexible to inform target group and helps in immediate feedback which ultimately helps in brand recall and brand interactivity (Labh, 2008). Using the right promotional tools and methods would help the organization to position its product in the right market. The old or similar advertisement in various segments is no longer effective. Brand ambassador should be selected carefully because sometime it may work in negative direction. Participation in national and international exhibitions is must to promote the product. The information seeker customer can evaluate the product and may decide accordingly. Creative advertising strategies like media selection, use of advertising tactics are to be planned and also specifying where the advertisement fits in. The advertising should be used as promotional tool but not to harm the society economically, politically and culturally.

\section{7) Crafting Communication and Sales Strategies}

Providing content and information to sales teams is never easy, hence communicating timely and effectively can change the business scenario of the company. The company has to deliver content to busy salespeople in relevant ways that work the way they need and also have to an ear to what sales needs and how they are using the content provided by the organization. The following issues may help the organization to compete in the market:

- Improve all the business fields and focus to find critical product information, industry best practices, win/loss stories, and competitive intelligence.

- Drive value for money across the entire sales process and train the employees. 
- Create a consistent closed loop feedback system from sales to marketing and back.

- Act as the backbone for driving a more prepared sales team with a longterm polices.

\section{8) Use of Internet in Marketing}

Today's business environment in such that even in a strong and more organized markets email and online marketers struggle to stay ahead of the competition. But these challenges are even more in the unorganized markets. It is important to spend sometime with the prominent Internet marketing expert. Establishing strong relations with the customer is only the beginning and keeping current customers engaged, increasing customer base and satisfying their needs and wants are vital for continued success in this competitive marketing environment.

\section{9) Revenue Generation ideation}

To survive and grow in the market it is highly important to generate revenue through continuously driving sales. Innovative productive ways will put marketing automation to work cost-effectively and efficiently resulting in generating more leads towards sales and revenue for the company. In the present time companies need to generate more referrals, from the customers to create new customer data base and also Re-selling, up-selling and cross-selling to the existing customers.

\section{CONCLUSION}

Presently business boundaries are shrinking and market is becoming more and more complex and difficult. The companies with new innovative market ideas will take lead over the others and this would determine the success of the business houses. Marketers need to focus on collecting new market information from all the sources rather than depending upon the sales and marketing personnel's. Use of latest technology, modern product designing and assurance of product quality at the highly competitive price is the need of present business system. Making product available at the right time in right quantity and at right place would turn the business in the favorable position. The companies need to update information on daily basis rather than weekly or fortnightly basis. The role of advertisement cannot be ignored in the modern era, as it helps the organization to reach out the masses. Creating company web-site, e-marketing and online selling would put the business on the front. Generating new ideas for the revenue and cost cutting will further help the organization to compete in the fierce competition more efficiently and effectively. Hence, marketers need to adopt new ideas in all aspects of business for survival and growth. 


\section{REFERENCES}

Chaston, Ian (1997), "Small Firm Performance Assessing the Interaction Between Entrepreneurial Style and Organizational Structure," European Journal of Marketing, 31 (11/12), pp. 814-831.

Joseph,W. Benoy; Robert,W. Cook; and Rajshekhar, G. Javalgi (2001), "Marketing on the Web:How Executive Feel, What Businesses Do," Business Horizone (July-August), pp. 32-40.

Labh, Shyama (2008), "Mobile Advertising: Another Dimension in Promotion," ICFAI Advertising Express, March, pp. 57-61.

Liu, Shuhua (1998), "Strategic Scanning and Interpretation Revisiting: Foundation for the Software Agent Support System-Part 1: Understanding the Concept and Context of Strategic Scanning." Industrial Management \& Data System, 98(7), pp. 295-312.

Meijboom, Bert; and Bart, Vos (1997), "International Manufacturing and Location Decisions," International Journal of Production Management, 17(8), pp. 790-805.

Muthiah, Krishnaveni (2006), "Marketing Paradigms and the Indian Firm: A Study of the Emerging Challenges and Firm Responses," Asia Pacific Journal of Marketing and Logistics, 18 (4), pp. 254-265.

Olivares, Albert Maydeu; and Nora, Lado (2003), "Market Orientation and Business Economic Performance: A Mediated Model", International Journal of Service Industry Management, 14 (3), pp. 284-309.

Ramachandran, Raja (2000), "Understanding the Market Environment of India," Business Horizone, January-February, pp. 44-52.

Urde, Mates (2003), "Core Value Based Corporate Brand Building," European Journal of Marketing, 37(7/8), pp. 1017-1040.

\section{ABOUT THE AUTHOR}

Raj Kumar Gautam, Assistant Professor, Punjabi University Regional Center for IT \& Management PhaseVII, Mohali, Punjab India, e-mail: raj5310@gmail.com. 